\title{
DIAMETRIC STRUCTURE OF A DECIDUOUS FOREST FRAGMENT IN THE AGRIBUSINESS REGION OF WESTERN SANTA CATARINA STATE, BRAZIL
}

\author{
ESTRUTURA DIAMÉTRICA DE UM FRAGMENTO DE FLORESTA DECIDUAL NA \\ REGIÃO DO AGRONEGÓCIO NO OESTE CATARINENSE
}

\author{
Welington Kiffer FREITAS ${ }^{1}$; Jorge FERREIRA ${ }^{1}$; Gérsica Dias NORONHA ${ }^{1}$; \\ Maria Clara Guedes RAMOS ${ }^{1}$; Patrick Motta Osório ESPER ${ }^{1}$ \\ 1. Universidade Federal Fluminense, Volta Redonda, RJ, Brasil.
}

\begin{abstract}
Forest structure studies may be carried out through the diametric distribution of individuals within a population, which is defined by characterizing the number of trees per unit area and diameter class intervals. The De Liocourt's q quotient can be used to assess the relationship between recruitment and mortality in forest communities because when a constant ratio occurs between the classes, it represents that the recruitment rate is similar to the mortality rate and the distribution can be considered as regular or balanced. This study aims to analyze the diametric structure of the arboreal component of a seasonal deciduous forest fragment located in the Peixe River Valley, Midwest of Santa Catarina State, Brazil. The sampled individuals were distributed in diameter classes with an amplitude of $5 \mathrm{~cm}$, in which the center of the first class presented a value of $6.5 \mathrm{~cm}$. Subsequently, the observed and estimated diametric distribution curves were constructed for the overall sampling and for species with the highest importance value (IV) and with different ecological attributes. The study area presented a deficit of trees in the overall and per species diameter classes when compared to a balanced forest. The De Liocourt's q quotient can be used to assess the diametric structure of deciduous forest fragments.
\end{abstract}

KEYWORDS: Forest ecology. De Liocourt's quotient. Management of forest fragments. Brazilian Atlantic Forest

\section{INTRODUCTION}

Biodiversity has been considered a strategic resource for supplying raw material in several economy sectors, not being restricted to timber production but also to a number of other non-timber products. It moreover provides important environmental services such as water and soil protection, ecosystem maintenance, climate improvement, and scenic, cultural, and psychological values (MACIEL et al., 2010, ROMEIRO, 2012, LOURO et al., 2013). Therefore, studies of forests, especially tropical ones, have been considered of extreme relevance (ALVES JR. et al., 2009).

The study of forest structure is not only justified for the knowledge of species that composes the flora, but especially to assess the arrangement, behavior, and mechanisms involved in the ecological succession process (FREITAS; MAGALHÃES, 2012). According to Alves Jr. et al. (2009), the structure of a forest can be explained by the diametric distribution of individuals. According to Lamprecht (1990), Felfili (1997), and Callegaro et al. (2012), the diameter distribution curve is represented by a negative exponential function, resembling an inverted J-shape.

According to Lamprecht (1990), this tendency can occur due to the numerous individuals grouped in the initial classes cannot overcome the competition until reaching the larger classes, some abiotic restriction, or even because some plants do not present the same diametric increase than others. The J-shaped distribution model reveals a positive fact in tropical forest ecosystems, indicating that the populations that make up a community are stable and self-regenerative (SCOLFORO, 1998). On the other hand, even "stable" communities can be dynamic due to mortality, growth, and recruitment rates (FELFILI, 1997).

The De Liocourt's q quotient can be used to assess the relationship between recruitment and mortality in forest communities because when a constant ratio occurs between the classes, it represents that the recruitment rate is similar to the mortality rate and the distribution can be regular or balanced (FELFILI et al., 1998).

The Midwest of Santa Catarina State, in Brazil, can be seen as the state's "granary," which results in significant environmental impacts due to agricultural activities such as soil and water 
pollution mainly from hog raising (SILVA; BASSI, 2012). There are also changes in matter and energy fluxes in the remaining forest ecosystems, resulting from an intensive use of agrochemicals and fertilizers in agriculture (VIBRANS et al., 2013). Besides, there is the dispersion of invasive plants such as the species Hovenia dulcis Thunb., introduced in Brazil in the 1970s and suitable for the afforestation of crops, pastures, and hedges, use in sawmills, and energy production (BAMPI et al., 2010). And finally, deforestation and timber and firewood extraction for multiple uses take place in local populations.

According to Vibrans et al. (2012), the degree of conservation of remnants of seasonal deciduous forests (SDF) in Santa Catarina State are quite worrying when compared to other associated ecosystems of the Atlantic Forest since the sum of fragment covers equal to or lower than 50 ha represents only $14 \%$ of the area covered by forests in the state. Thus, seasonal deciduous forests in southern Brazil are considered the most threatened and least protected ecosystems in the entire Atlantic Forest domain (VIBRANS et al., 2012).

Therefore, this study aimed to evaluate the diametric structure of the arboreal component of a seasonal deciduous forest fragment located in the Peixe River Valley, Midwest of Santa Catarina State, Brazil, based on the De Liocourt's q quotient.

\section{MATERIAL AND METHODS}

\section{Study area}

This study was carried out in a seasonal deciduous forest fragment located in the Peixe River Valley, municipalities of Piratuba and Ipira, Midwest of Santa Catarina State, Brazil (Figure 1). The fragment area has approximately 125 ha and is located between the geographical coordinates $27^{\circ} 25^{\prime} 34^{\prime \prime} \mathrm{S}$ and $51^{\circ} 47^{\prime} 18^{\prime \prime} \mathrm{W}$.

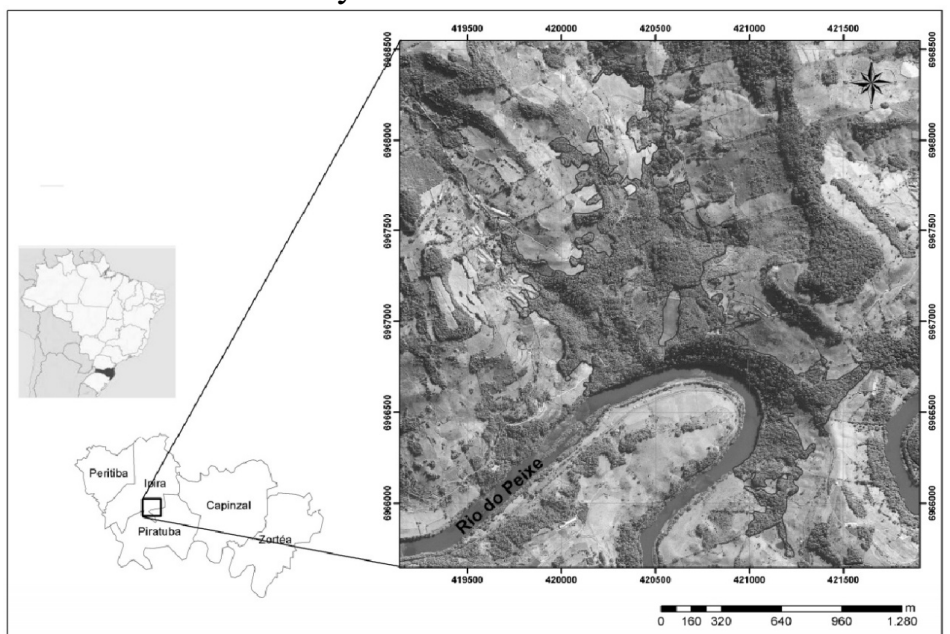

Figure 1. Location of the study area, a seasonal deciduous forest fragment, Peixe River Valley, Ipira and Piratuba, SC, Brazil

Peixe River Watershed is a tributary of the right bank of the Uruguay River Watershed, in the state's Midwest. The regional relief is composed of a wide plateau, showing distinct geomorphological features, with intensely dissected areas, controlled by geological structures, and inserted in the plateau of the Iguaçu and Uruguay rivers (FREITAS, 2012).

The study area belongs to the seasonal deciduous forest vegetation formation, which is formed by an emergent arboreal stratum represented by species of pantropical genera, including species adapted to leaf loss due to physiological drought caused by the winter cold during two months a year, with averages of temperature lower than $15{ }^{\circ} \mathrm{C}$ (IBGE, 2015, FREITAS et al., 2016a).

In this region, the humid mesothermal climate (Cfa) is predominant, with no distinct dry season, with monthly precipitations above $60 \mathrm{~mm}$, average temperatures of the warmest months above $22{ }^{\circ} \mathrm{C}$ and of the coldest month below $18{ }^{\circ} \mathrm{C}$ and above $3{ }^{\circ} \mathrm{C}$ (FREITAS et al., 2016a).

The heavily structurally controlled portions in the landscape, with steep slopes and deep valleys, present little or moderately developed soils (Inceptisol) whereas watershed portions with more smoothed relief present more developed soils (Oxisols) (FREITAS et al., 2016b).

\section{Proceedings}

Infield experiments were carried out from 2009 to 2010 . For the phytosociological survey, 14 plots of $1,000 \mathrm{~m}^{2}(10 \times 100 \mathrm{~m})$ were randomly allocated, totaling 1.4 ha of sampling. The circumference at breast height $(\mathrm{CBH})$, total height, common name, and dendrological features of all arboreal individuals with $\mathrm{CBH} \geq 12.57 \mathrm{~cm}$ 
(measured at $1.30 \mathrm{~m}$ from the ground) were recorded in order to facilitate the identification of the collected botanical material by means of consultations with specialists and specialized literature.

In order to classify the botanical families, the APG III system was (2009) adopted and the spelling of taxa was checked in electronic databases provided by the Botanical Garden of Rio de Janeiro (FLORA DO BRASIL, 2015).

The sampled individuals were distributed in diameter classes with an amplitude of $5 \mathrm{~cm}$ (ALVES JR. et al., 2009). After distributing the individuals at each diametric classes, diameter frequency was adjusted by a distribution function, as in Alves Jr. et al. (2009) (Equation 1):

$$
\ln y_{i}=\beta_{0}+\beta_{1}+x_{i}+\varepsilon_{i}
$$

Where: Ln y is the natural logarithm of the average frequency per diameter class, with an amplitude of $5 \mathrm{~cm}$, per hectare. In cases of the nonexistence of individuals in the classes, the number 1 (constant to all classes) was added to allow the calculation of the center of the diameter class (x), as proposed by Alves Jr. et al. (2009). In addition, $\beta_{0}$ and $\beta_{1}$ are the structural parameters of vegetation in relation to diameter distribution and $\varepsilon_{\mathrm{i}}$ is the random error.

Based on the adjusted distribution function, the specific q quotient was calculated by Equation 2, which considers the ratio between frequencies of a class of any diameter $\left(\mathrm{x}_{\mathrm{i}}\right)$ and the frequency immediately above $\left(\mathrm{x}_{\mathrm{i}+1}\right)$.

$$
\mathrm{q}=\frac{e^{\left(\beta_{0} \beta_{1} x_{i}\right)}}{e^{\left(\beta_{0} \beta_{1} x_{i+1}\right)}}
$$

After obtaining the q value, the curve of the difference between frequencies can be generated (observed and estimated) by recalculating the $\beta_{1 \mathrm{t}}$ value (Equation 3) to better understand the behavior of a certain species within a community.

$$
\beta_{1}=\frac{\ln (q)}{x_{(i)}-x_{(i-1)}}
$$

This study was based on species that totaled about $40 \%$ of the total importance value in the phytosociological survey carried out by Freitas et al. (2012c) (Tab. 1). However, the discussions were carried out emphasizing the ecological aspects (ecological group and the center of origin) and structural parameters (size and importance value).

Table 1. List of 19 species with the highest importance value (IV - \%) in descending order in a seasonal deciduous forest fragment, Peixe River Valley, Ipira and Piratuba, SC, Brazil: When: Basal Area (G $\mathrm{m}^{2}$ ); Individual number (N); Dispersal syndrome (DS); Ecological Group (EG); Origin (O)

\begin{tabular}{lllllll}
\hline Nome Científico & $\mathbf{N}$ & $\begin{array}{l}\mathbf{G} \\
\mathbf{( m}^{\mathbf{2}}\end{array}$ & $\begin{array}{l}\text { VI } \\
(\mathbf{\%})\end{array}$ & DS & EG & O \\
\hline Luehea divaricata Mart. & 142 & 5,1292 & 7,48 & ANE & SI & Native \\
Parapiptadenia rigida (Benth.) Brenan & 93 & 5,7390 & 7,08 & AUT & PI & Native \\
Casearia sylvestris Sw. & 131 & 1,2897 & 4,10 & ZOO & PI & Native \\
Ocotea puberula (Rich.) Nees & 56 & 2,1442 & 3,36 & ZOO & SI & Native \\
Cabralea canjerana (Vell.) Mart. & 69 & 1,9576 & 3,34 & ZOO & PI & Native \\
Actinostemon concolor (Spreng.) Müll. Arg. & 146 & 0,5532 & 3,27 & AUT & ST & Native \\
Cupania vernalis Cambess. & 106 & 1,1032 & 3,26 & ZOO & PI & Native \\
Apuleia leiocarpa (Vogel) J. F. Macbr. & 36 & 1,9952 & 2,92 & ANE & CL & Native \\
Nectandra megapotamica (Spreng.) Mez & 69 & 1,0305 & 2,76 & ZOO & PI & Native \\
Tabernaemontana catharinensis A. DC. & 49 & 0,6876 & 2,16 & ZOO & ST & Native \\
Sapium glandulosum (L.) Morong & 33 & 0,9342 & 2,12 & ZOO & PI & Native \\
Hovenia dulcis Thunb. & 48 & 0,8689 & 2,08 & ZOO & SI & Exotic \\
Guarea macrophylla Vahl & 77 & 0,2771 & 3,62 & ZOO & PI & Native \\
Sebastiania commersoniana (Baill.)L.B.Sm.\&Downs & 62 & 0,6654 & 2,92 & ZOO & SI & Native \\
Campomanesia xanthocarpa O. Berg & 45 & 0,7213 & 2,12 & ZOO & ST & Native \\
Inga marginata Willd. & 43 & 0,4978 & 2,02 & ZOO & PI & Native \\
Trichilia claussenii C. DC. & 47 & 0,7544 & 2,21 & ZOO & CL & Native \\
\hline Outras & $\mathbf{8 2 5}$ & $\mathbf{1 1 , 8 3 2 8}$ & $\mathbf{4 3 , 1 0}$ & - & - & - \\
\hline Total & $\mathbf{2 . 1 2 5}$ & $\mathbf{3 9 , 1 0 9 6}$ & $\mathbf{1 0 0}$ & - & - & - \\
\hline Adal
\end{tabular}

Adapted from: FREITAS (2012); FREITAS et al. (2016c) 


\section{RESULTS AND DISCUSSION}

The number of individuals per hectare found in the studied fragment forest was 1,517. This value is considered high when compared to the results obtained by the Floristic and Forest Inventory of Santa Catarina (IFFSC) (561.19 ind ha ${ }^{-1}$ ) for the Peixe River Watershed, whose inclusion criterion was a diameter at breast height $(\mathrm{DBH})$ of $10 \mathrm{~cm}$ (VIBRANS et al., 2013), and 1.116 and 677 ind ha for other two SDF fragments of the Alto Uruguay region, $\mathrm{SC}$ for a $\mathrm{DBH}>5.0 \mathrm{~cm}$ (RUSCHEL et al., 2009). The study registered the presence of 2,772 , which is equivalent to 1,980 boles $\mathrm{ha}^{-1}$.

The basal area was $26.15 \mathrm{~m}^{2} \mathrm{ha}^{-1}$, much higher than that recorded by IFFSC $\left(20.04 \mathrm{~m}^{2} \mathrm{ha}^{-1}\right)$ (VIBRANS et al., 2013), but lower than the value obtained by Schneider and Rocha (2014) $\left(29.5 \mathrm{~m}^{2}\right.$ $\mathrm{ha}^{-1}$ ), considering a DBH of $7.9 \mathrm{~cm}$ in a fragment located in the region of São Miguel do Oeste, SC. Basal area is an excellent descriptor to characterize structurally a forest community since it allows establishing comparisons with other ecosystems due to its direct relation to the vegetation biomass (DURIGAN, 2009). According to Vibrans et al. (2012), in Santa Catarina State, SDF ecosystems present a high variability in terms of basal area, probably due to canopy opening due to anthropic activities.

Regarding the forest community, DBH values ranged from 4.0 to $92.3 \mathrm{~cm}$ and approximately 1,700 individuals $(\sim 80 \%)$ were concentrated in the first two diameter classes. Felfili and Silva Junior (1988) also found this pattern (959 ind $\mathrm{ha}^{-1}$ or $85 \%$ of the diameters) between diametric classes from 5 to $13 \mathrm{~cm}$.

Still considering the diameter distribution of all individuals sampled in the community, the frequency curve adjusted by the Meyer equation presented a frequency polygon with a slight tendency of an inverted J-shape, as referred to uneven-aged forests (FELFILI; SILVA JÚNIOR, 1988; ALVES Jr. et al., 2009; LOPES et al., 2011; CALLEGARO et al., 2012).

Figure 2 shows the deficits of individuals in the diametric classes from the midpoint of $26.5 \mathrm{~cm}$. The reduction factor of the number of individuals from one class to the next did not occur in a constant way since the De Liocourt's q constant (observed) did not remain the same for all diametric classes of the population, which means a not perfectly balanced community (FELFILI; SILVA JÚNIOR, 1988).

\section{Forest Fragment}

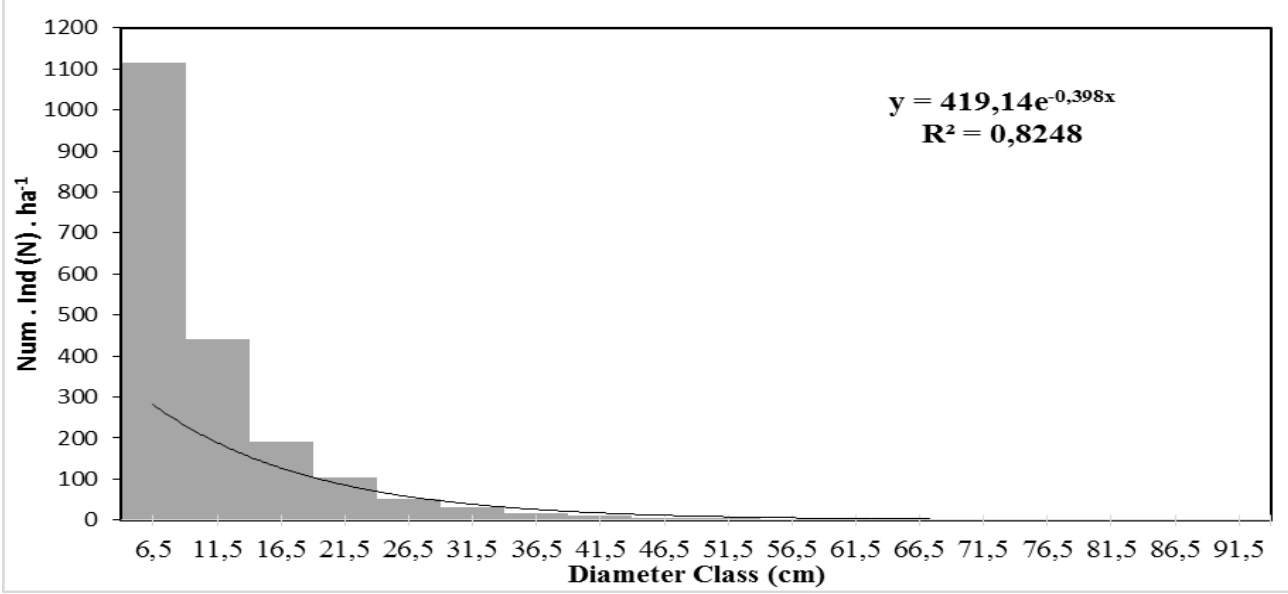

Figure 2. Observed and estimated diametric distribution curves of the arboreal component of a deciduous forest fragment located in the Midwest of Santa Catarina State, Brazil

According to Nunes et al. (2003), the great number of small and thin individuals may indicate the occurrence of severe disturbances in the past. In this sense, this behavior suggests an imbalance between mortality and recruitment rates of individuals in the arboreal component, causing changes in forest dynamics. However, Martins (1991) pointed out that the highest density of smaller individuals does not always indicate a lack of regeneration problems, so detailed analyses using a representative group of species are required for interpretations that are more realistic on diametric distributions. According to IFFSC, due to the high degree of anthropic pressure during the different economic cycles, the diametric distributions of SDF in Santa Catarina are very deficient, especially for higher diameter classes (VIBRANS et al., 2012).

The diametric distribution analysis considered the species that stood out in terms of IV in the study of Freitas et al (2016), with different 
ecological characteristics: Luehea divaricata, Parapiptadenia rigida, Actinostemon concolor, Trichilia claussenii, and Hovenia dulcis (Klein, 1978). The first four are autochthonous and generalist species in SDF whereas $H$. dulcis is an exotic invasive species with a strong emphasis on deciduous formations in southern Brazil (Lima et al., 2015).

According to Carvalho (2003), L. divaricata belongs to the family Malvaceae, being commonly known as açoita-cavalo. It occurs naturally in eastern Brazil, northeastern Argentina, eastern Paraguay, and northern Uruguay, with an altitudinal variation from 30 (Rio Grande do Sul State, Brazil) to $1,400 \mathrm{~m}$ (Minas Gerais State, Brazil). According to Vibrans et al. (2012) in SDF of Santa Catarina, its density was $27.63 \pm 6.91$ ind ha ${ }^{-1}$ considering a DBH higher than $10 \mathrm{~cm}$. In our study, L. divaricata occurred at a density of 102 ind ha ${ }^{-1}$ when adopting the inclusion criterion of $4 \mathrm{~cm}$. Figure 3 shows that about $60 \%$ of the sampled individuals are distributed between classes from 4 to $14 \mathrm{~cm}$, with a $\mathrm{q}$ ratio of 0.6 between them and an irregular distribution from $31.5 \mathrm{~cm}$ (figure3).

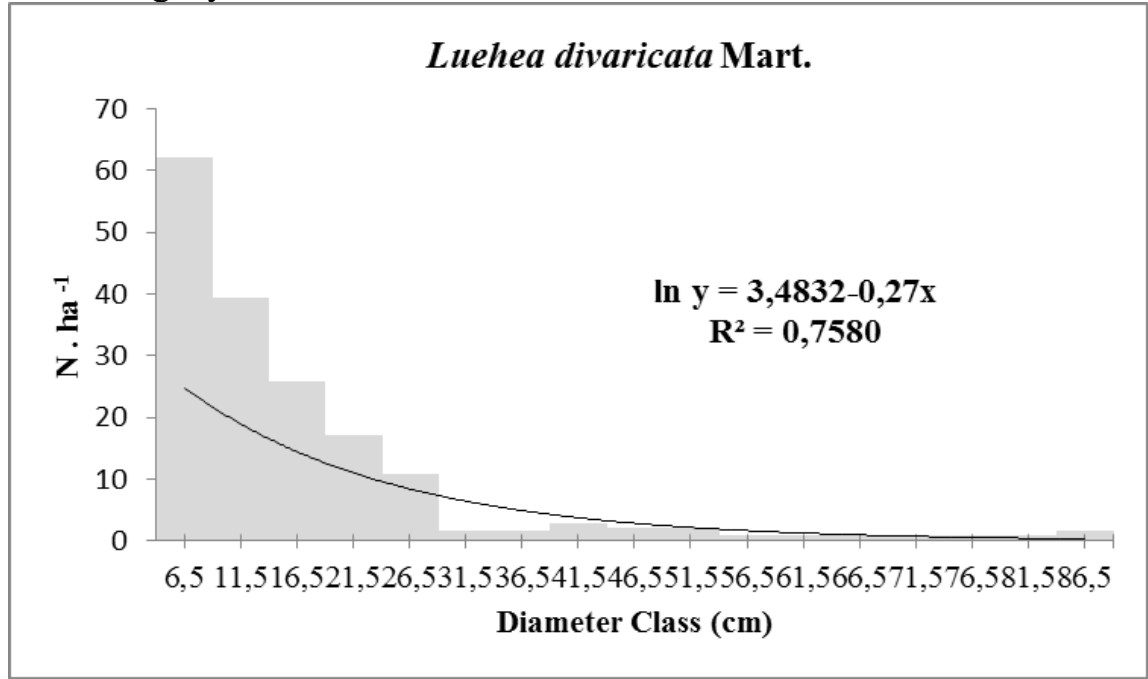

Figure 3. Observed and estimated diametric distribution curves of Luehea divaricata found in a deciduous forest fragment located in the Midwest of Santa Catarina State, Brazil

This same behavior was observed in IFFSC, considering the multiple use character of the species, such as sawn wood, round wood, in civil construction, posts, railway sleepers, tool cables, energy (firewood and poor quality charcoal), cellulose pulp, and other purposes (CARVALHO, 2003; VIBRANS et al., 2012). This may be pressing the use of this species and increasing its illegal extraction in the largest diameter classes.

According to Carvalho (2003), P. rigida belongs to the family Fabaceae, commonly known as angico-amarelo, being a pioneer tree that presents an autochoric seed dispersion. It occurs in the region between the Brazilian states Espírito Santo and Rio Grande do Sul, including dry regions of Mato Grosso do Sul and Minas Gerais, with an altitudinal variation from 30 (Rio Grande do Sul) to $1,100 \mathrm{~m}$ (Santa Catarina). In addition, this species can be found in northeastern Argentina, eastern Paraguay, and northern Uruguay. In the SDF of Santa Catarina, its density was DBH $\geq 10 \mathrm{~cm}$ (VIBRANS et al., 2012). About 64 ind ha ${ }^{-1}(\mathrm{DBH} \geq 4 \mathrm{~cm})$ were found in the studied fragment. $P$ rigida showed a higher concentration of individuals up to $11.5 \mathrm{~cm}$. The q ratio was equal to 0.6 up to the class of 24 $\mathrm{cm}$, with variations from 0.13 to 2.00 in the upper classes, indicating an irregular distribution, including discontinuities in different average diameters $(36.5,46.5$, and $56.5 \mathrm{~cm})$ (Figure 4).

Clandestine exploration may be affecting the permanence of individuals with higher diameters in the forest structure most probably due to the high commercial value of its wood. This fact can be justified by the low density of $P$. rigida $(6.95 \pm 2.87$ ind $\mathrm{ha}^{-1}$ ) found in IFFSC (VIBRANS et al., 2012).

The species A. concolor (Euphorbiaceae) is a characteristic tree of the seasonal forest, occurring in the region between the Brazilian states Ceará and Rio Grande do Sul. It reaches from 2 to $10 \mathrm{~m}$ in height and 18 to $35 \mathrm{~cm}$ in $\mathrm{CBH}$, being common in the subcanopy, but infrequent in clearings and borders (ALBERTI; MORELLATO, 2008). Our study presented a high density $\left(104\right.$ ind ha $\left.{ }^{-1}\right)$, with more than $92 \%$ of individuals with DBH in the class of $4.0 \mathrm{~cm}$, with a discontinuity in the upper classes (Figure 5). This species presents a typical pattern of 
understory occupation, as described by Klein (1978)

and corroborated by Vibrans et al. (2012).

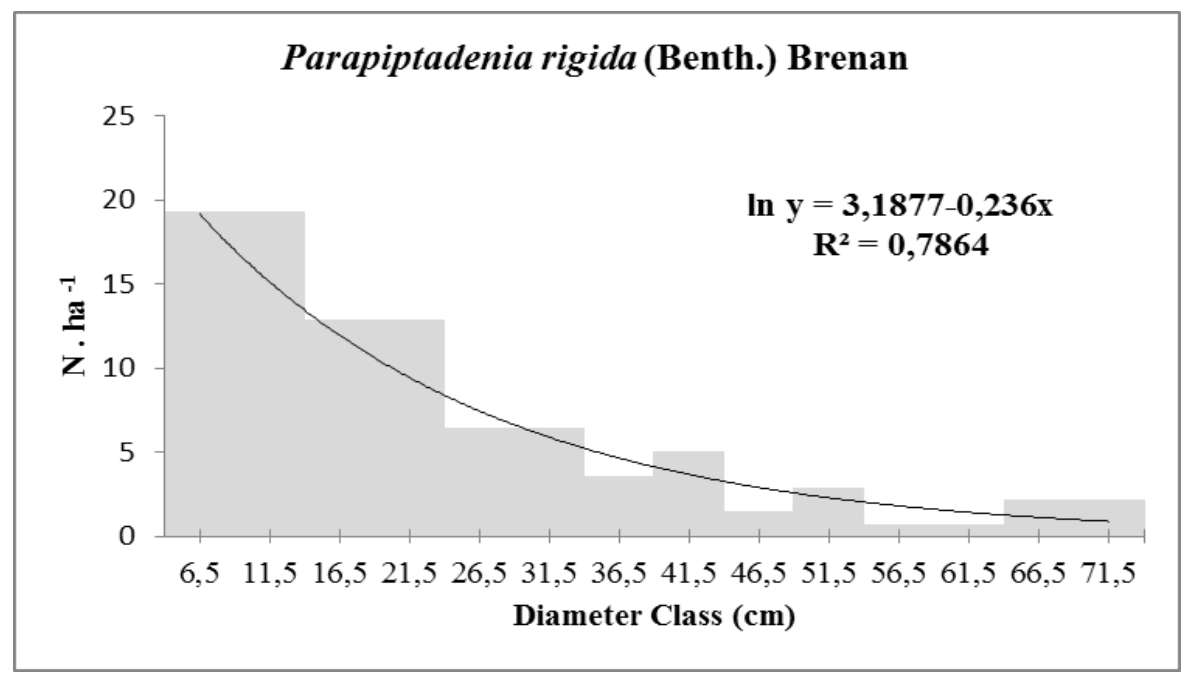

Figure 4. Observed and estimated diametric distribution curves of Parapiptadenia rigida found in a deciduous forest fragment located in the Midwest of Santa Catarina State, Brazil

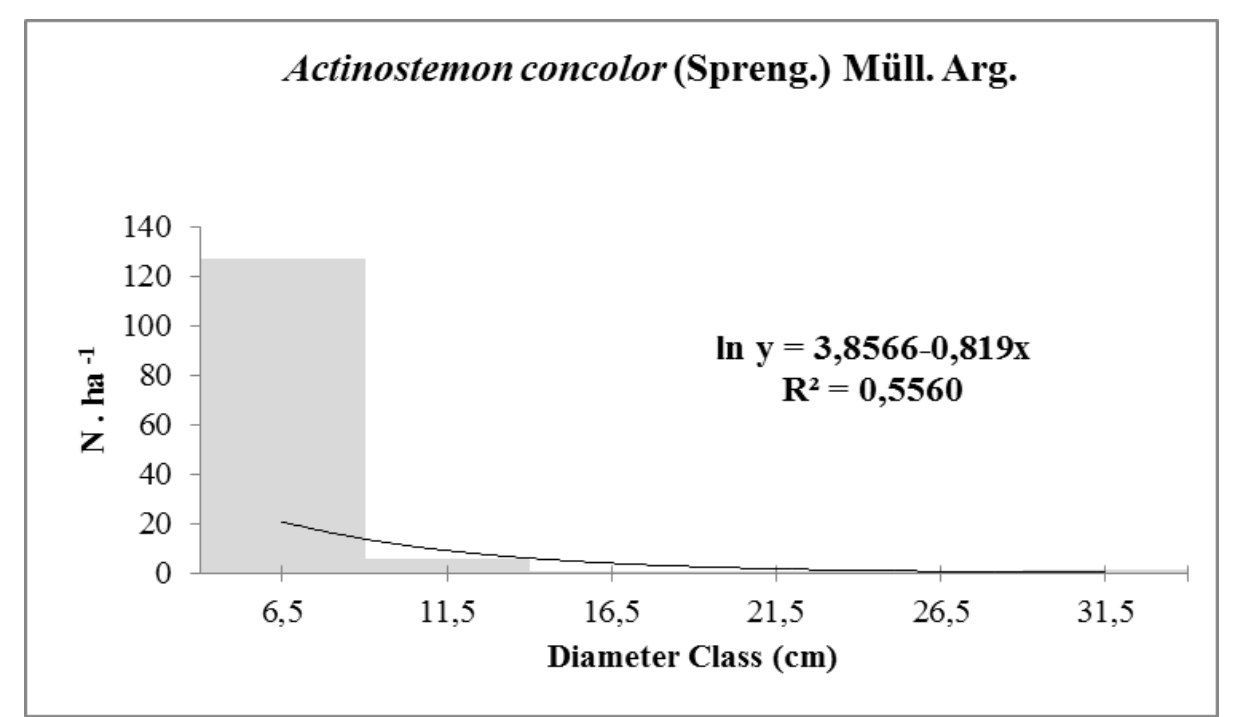

Figure 5. Observed and estimated diametric distribution curves of Actinostemon concolor found in a deciduous forest fragment located in the Midwest of Santa Catarina State, Brazil

The species $H$. dulcis belongs to the family of Rhamnaceae, commonly called Japanese raisin tree. It has as the center of origin the Asia, in regions with high-altitude tropical and subtropical climates. It is a plant with spontaneous and aggressive growth, developing well both inside and at the edge of forests (FREITAS et al., 2016b.). This species occupied the eleventh position among the most important species in SDF of Santa Catarina according to IFFSC (VIBRANS et al., 2013). $H$. dulcis composes a new physiognomy of vegetation and causes an increase in the basal area of remnants mainly because it has a strong interaction with the autochthonous fauna, which favors its dispersion
(VIBRANS et al., 2013). In our study, this species presented a density of 34 ind ha ${ }^{-1}$. Figure 6 shows that the first class presents a lower number of individuals than the subsequent, with a very heterogeneous $\mathrm{q}$ ratio $(0.27 \leq \mathrm{q} \leq 1.83)$. In addition, the number of larger individuals is also reduced, which could indicate problems of natural regeneration (FELFILI; SILVA JUNIOR, 1988). Possibly, the introduction of this species in the fragment occurred due to some pronounced disturbance (clearing, edge effect, etc.). However, in recent days, the ecosystem resilience is probably having a more difficulty in recruiting this species. 


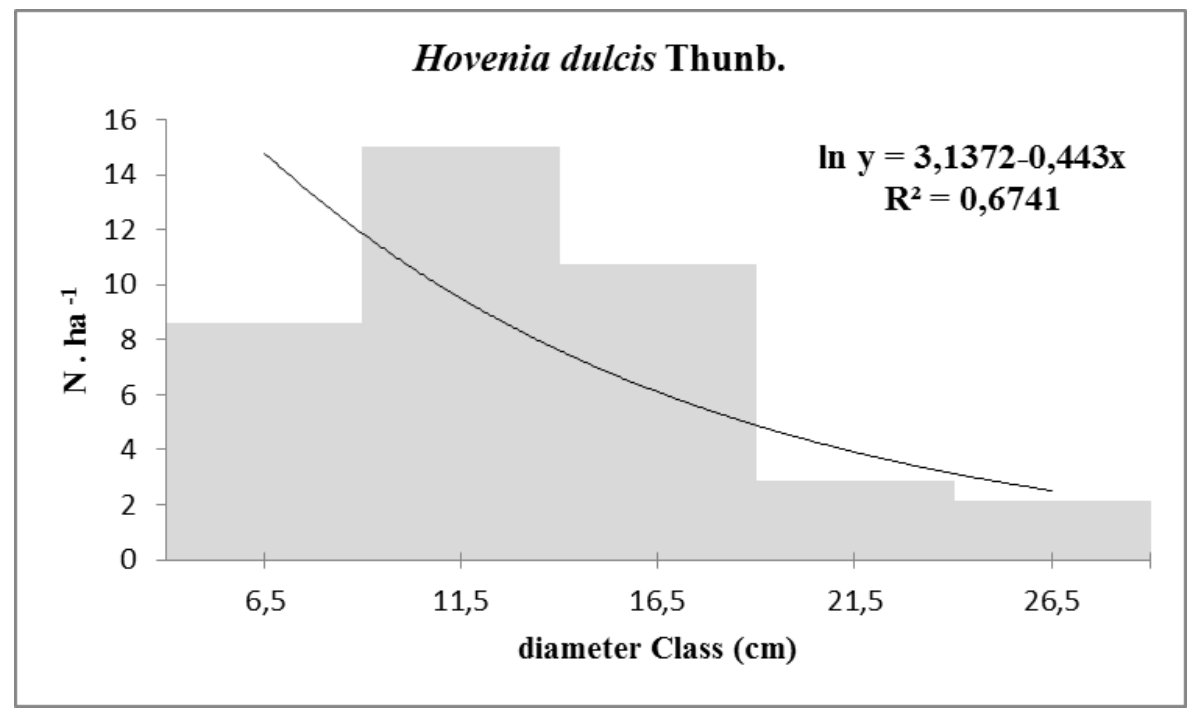

Figure 6. Observed and estimated diametric distribution curves of Hovenia dulcis found in a deciduous forest fragment located in the Midwest of Santa Catarina State, Brazil

T. claussenii (Meliaceae) is a commonly known as catiguá, occurring in the region between the Brazilian states Minas Gerais, Mato Grosso and Rio Grande do Sul in seasonal formations typical of well-preserved forests (LORENZI, 1992). In our study, this species presented a density of 34 ind $\mathrm{ha}^{-1}$, indicating ingression problems from the average diameter of $16.5 \mathrm{~cm}$ (Figure 7), with a $\mathrm{q}$ quite oscillating. This same pattern was observed in IFFSC, suggesting the possibility of overexploiting this species and de-characterizing its original population since it has a light wood suitable for carpentry (linings, wainscoting, internal finishing in civil construction, and others) (LORENZI, 1992; VIBRANS et al., 2012).

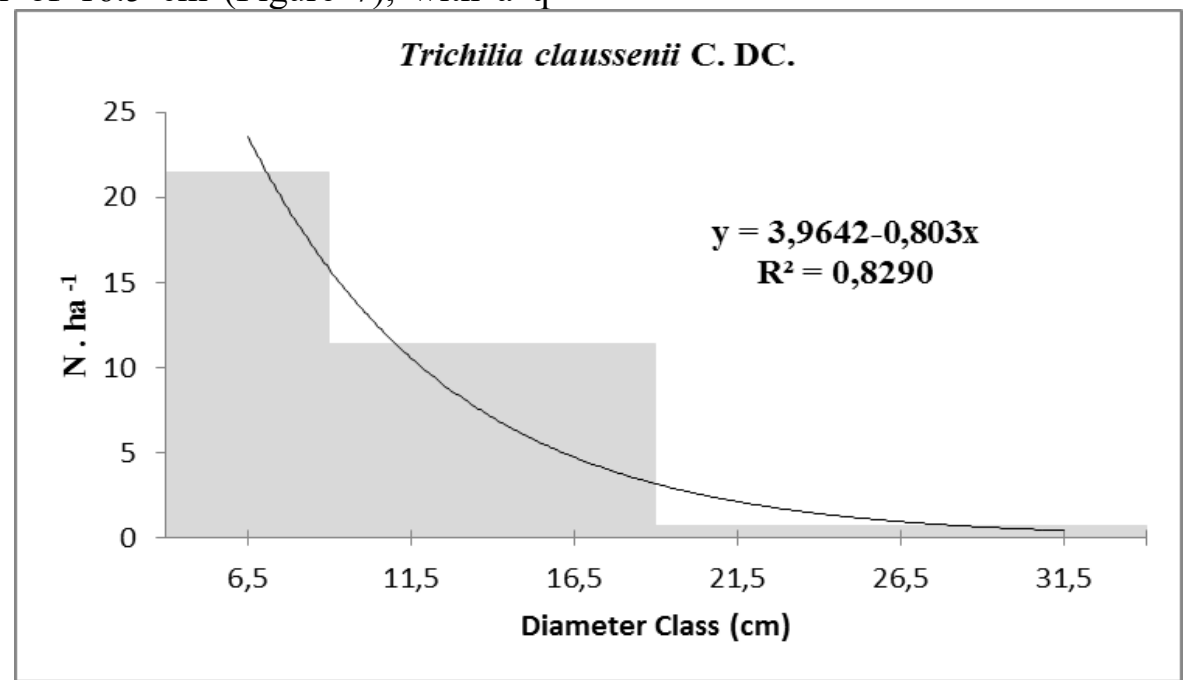

Figure 7. Observed and estimated diametric distribution curves of Trichilia claussenii found in a deciduous forest fragment located in the Midwest of Santa Catarina State, Brazil

However, those local rare species, which are found in up to 1 ind. ha ${ }^{-1}$, can recruit new individuals in lower diameter classes with factors inherent to fragmentation such as dispersing agents, shape, and size of areas (MACHADO et al., 2004). Therefore, problems associated with mortality/recruitment should also consider the population ecology of each species (FELFILI, 1997).

\section{CONCLUSIONS}

The studied fragment showed a diametric structure with a slight tendency of an inverted Jshape, but it still concentrates some signs of structure imbalance.

The obtained values for the De Liocourt's q coefficient show that the degree of disturbance in the fragment occurs constantly.

More demanding species regarding their 
habitats, such as Actinostemon concolor and Trichilia claussenii, have high recruitment rates, but with a more difficult to establish in the community.

Hovenia dulcis, an invasive exotic species, potentially occupies impacted areas, but when the community presents a good resilience, it seems to find a greater difficulty for the effective establishment.

RESUMO: Estudos de estrutura florestal podem ser realizados através da distribuição dos diâmetros de indivíduos dentro de uma população, que é definida pela caracterização do número de árvores por unidade de área e intervalos de classe de diâmetro. $\mathrm{O}$ quociente $\mathrm{Q}$ de De Liocourt pode ser usado para avaliar a relação entre recrutamento e mortalidade nas comunidades florestais, porque quando uma relação constante ocorre entre as classes, ela representa que a taxa de recrutamento é semelhante à taxa de mortalidade e a distribuição pode ser considerada como regular ou equilibrado. Este estudo tem como objetivo analisar a estrutura diamétrica do componente arbóreo de um fragmento da floresta decidual localizado na região do vale do Rio Peixe, meio-oeste do Estado de Santa Catarina, Brasil. Os indivíduos amostrados foram distribuídos em classes de diâmetro com uma amplitude de $5 \mathrm{~cm}$, no qual o centro da primeira classe apresentou um valor de $6,5 \mathrm{~cm}$. Posteriormente, as curvas de distribuição dos diâmetros observadas e estimadas foram construídas para a amostragem global e para espécies com maiores valores de importância (IV) e com diferentes atributos ecológicos. A área de estudo apresentou déficit de árvores nas classes de diâmetro geral e por espécie em comparação com uma floresta equilibrada. O quociente $Q$ de De Liocourt pode ser usado para avaliar a estrutura diametral dos fragmentos de floresta deciduais.

PALAVRAS-CHAVE: Ecologia florestal. Quociente Q de De Liocourt. Manejo de fragmentos florestais. Mata Atlântica

\section{REFERENCES}

ALBERTI, L. F.; MORELLATO, L. P. C. Influência da abertura de trilhas antrópicas e clareiras naturais na fenologia reprodutiva de Gymnanthes concolor (Spreng.) Müll. Arg. (Euphorbiaceae). Rev. bras. Bot., v. 31 , n. 1, p. 53-59, 2008. http://dx.doi.org/10.1590/S0100-84042008000100006.

ALVES JR., F. T., FERREIRA, R. L. C.; SILVA, J. A. A.; MARANGON, L. C.; COSTA Jr., R. F. R. Estrutura diamétrica de um fragmento de Floresta Atlântica em matriz de cana-de-açúcar, Catende, Pernambuco. Rev. bras. eng. agríc. ambient, v. 13, n. 3, p. 328-333, 2009. https://doi.org/10.1590/S1415-43662009000300015

APG III. An update of the Angiosperm Phylogeny Group classification for the orders and families of flowering plants: APG III. Botanical Journal of the Linnean Society, v. 161, n. 2, p. 105-121, 2009. https://doi.org/10.1111/j.1095-8339.2009.00996.x

BAMPI, M.; BICUDO, M. O. P.; FONTOURA, P. S. G.; RIBANI, R. H. Composição centesimal do fruto, extrato concentrado e da farinha da uva-do-japão. Cienc. Rural, v. 40, n.11, p.2361-2367, 2010. http://dx.doi.org/10.1590/S0103-84782010001100018.

CAlleGARO, R. M.; LONGHI, S. J.; ARAUJO, A. C B; KANIESKI, M. R.; FLOSS, P. A.; GRACIOLI, C. R. Estrutura do componente arbóreo de uma Floresta Estacional Decidual ripária em Jaguari, RS. Cienc. Rural, v. 42, n. 2, p. 305-311, 2012. http://dx.doi.org/10.1590/S0103-84782012000200019.

CARVALHO, P. E. R. Espécies arbóreas brasileiras. Brasília: Embrapa Informação Tecnológica; Colombo: Embrapa Florestas. 2003. v. 1. 1039p.

DURIGAN, G. Estrutura e diversidade de florestas tropicais. In: MARTINS, S. V. (org). Ecologia de Florestas Tropicais do Brasil. 2. ed. Viçosa: Editora UFV, 2009. pp. 185-215. 
FELFILI, J. M.; SILVA JR., M. C.. Distribuição dos diâmetros numa faixa de cerrado na fazenda Agua Limpa (FAL) em Brasilia-DF. Acta bot. bras., v. 2 , n. 1-2, p. 85-104,1988.

http://repositorio.unb.br/handle/10482/10371.

FELFILI, J. M. Diameter and height distributions in a gallery forest community and some of its main species in central Brazil over a six-year period (1985-1991). Rev. bras. Bot. v. 20, n.2, p.155-162, 1997.

http://dx.doi.org/10.1590/S0100-84041997000200006.

FELFILI, J. M.; SILVA JR., M. C.; NOGUEIRA, P. E. Levantamento da vegetação arbórea na região de Nova Xavantina, MT. Boletim do Herbário Ezechias Paulo Heringer, v. 3, p. 63-81, 1998.

FLORA BRASIL. 2015. LISTA de espécies da flora do Brasil. Available in: http://floradobrasil.jbrj.gov.br/jabot/listaBrasil/PrincipalUC/PrincipalUC.do;jsessionid=79819F05DBBDC5C5 9B0FF982F3A58D25 Accessed in: 14 jan. 2017.

FREITAS, W. K.; MAGALHAES, L. M. S. Vertical structure of the arboreal component under regeneration phase of a deciduous forest fragment, Santa Catarina State, Brazil. Rev. Árvore, v. 40, n. 5, p. 781-791, $2016 \mathrm{a}$. http://dx.doi.org/10.1590/0100-67622016000500002.

FREITAS, W. K.; MAGALHAES, L. M. S.; VIVÈS, L. R. Floristic diversity and spatial distribution of tree species in a dry forest in southern Brazil. Applied Ecology and Environmental Research, v. 15, n. 1, p. 511524, 2016b. http://dx.doi.org/10.15666/aeer/1501_511524.

FREITAS, W. K.; MAGALHAES, L. M. S.; BOURSCHEID, K.; LUZ, R. V. Estrutura horizontal de um trecho da Floresta Decidual da região oeste de Santa Catarina, Brasil. Ambiência, v. 12, n. 1, p. 217-232, 2016c. DOI: 10.5935/ambiencia.2016.01.13. https://doi.org/10.5935/ambiencia.2016.01.13

FREITAS, W. K.; MAGALHÃES, L. M. S. Métodos e parâmetros para estudo da vegetação com ênfase no estrato arbóreo. Floresta Ambient., v. 19, n. 4, p. 520-539, 2012. http://dx.doi.org/10.4322/floram.2012.054.

FREITAS, W. K. Composição, estrutura e a ecologia histórica de um trecho de Floresta Estacional Decidual do meio oeste catarinense, Brasil. Thesis (DSc.) - Universidade Federal Rural do Rio de Janeiro. Instituto de Florestas: Seropédica, 2012.

IBGE. Instituto Brasileiro de Geografia e Estatística, 2017. Mapa da vegetação do Brasil. http://www.ibge.gov.br/home/geociencias/default_prod.shtm. Acessed in: 22 mar. 2017.

KLEIN, R. M. Mapa fitogeográfico do Estado de Santa Catarina.In: REITZ, R. Flora Ilustrada Catarinense. Itajaí: Herbário Barbosa Rodrigues, 1978. pp. 1-16p.

LAMPRECHT, H. Silvicultura nos trópicos: Ecossistemas florestais e respectivas espécies arbóreas possibilidades e métodos de aproveitamento sustentado. Eschborn: Instituto de Silvicultura da Universidade Gottingen, República Federal da Alemanha, 1990. 343 p.

Lima, R. E. M.; Dechoum, M. S.; Castellani, T. T. 2015. Native seed dispersers may promote the spread of the invasive Japanese raisin tree (Hovenia dulcis Thunb.) in seasonal deciduous forest in southern Brazil. Tropical Conservation Science, v. 8, n. 3, p. 846-862, 2015. Available online: www.tropicalconservationscience.org. Acessed in: 20 jun. 2017.

LOPES, S. F.; SCHIAVINI, I.; PRADO JÚNIOR, J. A.; GUSSON, A. E.; SOUZA NETO, A. R.; VALE, V. S.; DIAS NETO, O. C. Caracterização ecológica e distribuição diamétrica da vegetação arbórea em um remanescente de Floresta Estacional Semidecidual, na fazenda experimental do Glória, Uberlândia. Biosci. J., v. 27 , n. 2, p. 322-335, 2011. 
LORENZI, H. Árvores Brasileiras: Manual de Identificação e Cultivo de Plantas Arbóreas Nativas do Brasil. Nova Odessa: Instituto Plantarum de Estudos da Flora, 1998. v. 1. 368 p.

LOURO, G.; REGO, F.; MONTEIRO, M; MACHADO, H. As Fileiras Baseadas na Floresta: Análise Sectorial. Silva Lus., v. 21, no. Especial, p. 01-19, 2013.

MACHADO, E. L. M; OLIVEIRA-FILHO, A. T.; CARVALHO, W. A. C.; SOUZA, J. S.; BORÉM, R. A. T.; BOTEZELLI, L.. Análise comparativa da estrutura e flora do compartimento arbóreo-arbustivo de um remanescente florestal na fazenda Beira Lago, Lavras, MG. Rev. Árvore, v. 28, n. 4, p. 499-516, 2004. http://dx.doi.org/10.1590/S0100-67622004000400005.

MACIEL, R. C. G.; REYDON, B. P.; COSTA, J. A.; SALES, G. O. O. Pagando pelos serviços ambientais: uma proposta para a Reserva Extrativista Chico Mendes. Acta Amaz., v. 40, n. 3, p. 489-498, 2010. http://dx.doi.org/10.1590/S0044-59672010000300007.

MARTINS, F. R. Estrutura de uma floresta mesófila. Campinas: Unicamp. 1991. 246p.

NUNES, Y. R. F.; MENDONÇA, A. V. R.; BOTEZELLI, L.; MACHADO, E. L. M.; OLIVEIRA FILHO, A. $\mathrm{T}$. Variações da fisionomia da comunidade arbóreos em um fragmento de Floresta Semidecidual em Lavras, MG. Acta bot. bras., v. 17, n. 3, p. 213-229, 2003. http://dx.doi.org/10.1590/S0102-33062003000200005.

ROMEIRO, A. R. Desenvolvimento sustentável: uma perspectiva econômico-ecológica. Estud. av, v. 26, n. 74, p. 65-92, p.2012. http://dx.doi.org/10.1590/S0103-40142012000100006.

RUSCHEL, A. R.; GUERRA, M. P.; NODARI, R. O. Estrutura e composição florística de dois fragmentos da Floresta Estacional Decidual do Alto Uruguai, SC. Rev. Ci. Flor., v. 19, n. 2, p. 225-236, 2009. https://doi.org/10.5902/19805098413

SCHNEIDER, G. ; ROCHA, F. Levantamento florístico e fitossociológico do componente arbóreo de um fragmento de Floresta Estacional Decidual em São Miguel do Oeste, Santa Catarina. Biotemas, v. 27, n. 2, p. 43-55, 2014. http://dx.doi.org/10.5007/2175-7925.2014v27n2p43.

SILVA, C. L.; BASSI, N. S. S. Análise dos impactos ambientais no oeste catarinense e das tecnologias desenvolvidas pela Embrapa Suínos e Aves. Informe Gepec, v. 16, n. 1, p. 128-143, 2012.

VIBRANS, A. C.; MC ROBERTS, R. E.; LINGNER, D. V.; MOSER, P.; NICOLETTI, A. Extensão original e remanescentes da Floresta Estacional Decidual em Santa Catarina. In: VIBRANS, A. C.; SEVEGNANI, L.; GASPER, A. L.; LINGNER, D. V. (eds.). Inventário Florístico Florestal de Santa Catarina, Vol. II, Floresta Estacional Decidual. Blumenau: Edifurb, 2012. p. 25-31.

VIBRANS, A. C.; SEVEGNANI, L.; GASPER, A. L.; MÜLLER, J. J. V.; REIS, M. S. Inventário florístico florestal de Santa Catarina: resultados resumidos. Blumenau: FURB / CCA - UFSC / Epagri, 2013.37p. 